\title{
Aerobic and Anaerobic Uptake of Sugars in Schizosaccharomyces pombe
}

\author{
By MILAN HÖFER* AND FATMA R. NASSAR† \\ Botanisches Institut der Universität, Kirschallee 1, 5300 Bonn, FRG
}

(Received 23 May 1986; revised 27 February 1987)

\begin{abstract}
Aerobic cells of the yeast Schizosaccharomyces pombe accumulated 2-deoxy-D-glucose (2-DOG) and glucosamine, but were unable to accumulate 3- $O$-methyl-D-glucose, 6-deoxy-D-glucose, D-xylose and D-arabinose. Uptake of all sugars tested displayed saturation kinetics; however, only 2-DOG, glucosamine and D-glucose exhibited mutual competitive inhibition of uptake and the phenomenon of exchange transport. Thus, they share a common 'glucose transport system'. Uncouplers inhibited sugar accumulation or induced sugar outflow from preloaded cells. The uptake of sugars of the glucose transport system was $\mathrm{pH}$ dependent and was accompanied by a stoicheiometric cotransport of $\mathrm{H}^{+}$. Since millimolar concentrations of the lipophilic cation tetraphenylphosphonium (which depolarizes the membrane potential) prevented sugar accumulation, the transport was electrogenic. Thus, the glucose carrier is a $\mathrm{H}^{+}$-symporter. Accumulation of sugars was inhibited by the plasma membrane ATPase inhibitors Dio-9 and $N, N^{\prime}$-dicyclohexylcarbodiimide. Anaerobic cells of $S$. pombe were virtually unable to transport 2-DOG and glucosamine. However, when energized by glucose, the accumulation of both sugars was completely restored. This anaerobic transport was also catalysed by the glucose carrier.
\end{abstract}

\section{INTRODUCTION}

The transport of sugars across yeast plasma membranes has been studied only in a few yeast species (for a review see Eddy, 1982). In most of the transport systems studied, the driving force for sugar uptake is the electrochemical proton gradient, $\Delta \bar{\mu}_{\mathrm{H}^{+}}$, generated by a plasmamembrane-bound $\mathrm{H}^{+}$-ATPase (Goffeau \& Boutry, 1986). The sugar molecules are translocated in symport with $\mathrm{H}^{+}$.

Among the plasma-membrane-bound $\mathrm{H}^{+}$-ATPases in fungi (for a review see Goffeau \& Slayman, 1981) two have been investigated in membrane vesicle studies. Scarborough (1976) used plasma membrane vesicles from Neurospora crassa to prove that the ATPase functions as an electrogenic $\mathrm{H}^{+}$-pump. Villalobo and co-workers used reconstituted proteoliposomes to demonstrate that the plasma membrane ATPase of the fission yeast Schizosaccharomyces pombe very likely catalyses the electrogenic $\mathrm{H}^{+}$-efflux and the compensating $\mathrm{K}^{+}$-influx (Villalobo et al., 1981; Villalobo, 1982). However, neither of these systems were used for studies of the energetic coupling between the $\mathrm{H}^{+}$-ATPase and the $\mathrm{H}^{+}$/sugar symport.

In $S$. pombe, sugar transport has not been studied in detail. Goffeau and his group (Foury \& Goffeau, 1975; Goffeau et al., 1975) reported that uptake of sucrose and of 2-deoxyglucose by the respiratory mutant $S$. pombe COB5 displays saturation kinetics, and is dependent on intracellular ATP as well as on a pH gradient across the plasma membrane. No attempt was made to elucidate the transport mechanism. Since plasma membranes of $S$. pombe can readily be

† Present address: Ain Shams University, Faculty of Science, Department of Microbiology, Cairo, Egypt.

Abbreviations: 2-DOG, 2-deoxy-D-glucose; 3-OMG, 3-O-methyl-D-glucose; 6-DOG, 6-deoxy-D-glucose ; DNP, 2,4-dinitrophenol; CCCP, carbonylcyanide $m$-chlorophenylhydrazone; $\mathrm{TPP}^{+}$, tetraphenylphosphonium; $\mathrm{DCCD}$, $N, N^{\prime}$-dicyclohexylcarbodiimide; $\Delta \psi$, membrane potential (difference of electrical potential across the plasma membrane); $\Lambda \bar{\mu}_{\mathrm{H}^{+}}$, electrochemical gradient of $\mathrm{H}^{+}$. 
fractionated from cell-free homogenates (Delhez et al., 1977), their reconstitution as plasma membrane vesicles is of potential importance for the following aim: provided that sugars are translocated in symport with protons, the energetic link between the primary $\mathrm{H}^{+}$-pumping ATPase (Villalobo et al., 1981) and the secondary $\mathrm{H}^{+} /$sugar symport can be established.

In this paper we analyse the kinetics and characterize the energetics of sugar uptake in $S$. pombe. Since $S$. pombe is a facultative anaerobic yeast, transport properties were compared under both aerobic and anaerobic conditions. This comparison is also important with regard to the so-called Kluyver effect and the problem of oxygen requirement for active sugar transport in yeasts (cf. Sims \& Barnett, 1978; Barnett \& Sims, 1982).

\section{METHODS}

Organism and growth. Schizosaccharomyces pombe $\left(972 \mathrm{~h}^{-}\right)$was grown in a medium containing $6 \%(\mathrm{w} / \mathrm{v})$ glucose and $2 \%(\mathrm{w} / \mathrm{v})$ yeast extract. The $\mathrm{pH}$ was adjusted to $4.5 \mathrm{with} \mathrm{HCl}$ before autoclaving. A preculture $(10 \mathrm{ml}) \mathrm{was}$ inoculated with one loop of cells and cultivated for $15-17 \mathrm{~h}$ on a gyratory shaker at $30{ }^{\circ} \mathrm{C}$; the preculture was used to inoculate the main culture $(100 \mathrm{ml})$. After a further $24 \mathrm{~h}$, the cells were harvested by centrifugation, washed three times with distilled water, and aerated for $1-4 \mathrm{~h}$ as a $5 \%$ (fresh wt/vol.) suspension.

Transport experiments. The uptake and accumulation of ${ }^{1+} \mathrm{C}$-labelled 2-deoxy-D-glucose (2-DOG), glucosamine, 3-O-methyl-D-glucose (3-OMG) and 6-deoxy-D-glucose (6-DOG) were measured as described by Niemietz et al. (1981); the uptake of D-xylose and D-arabinose was measured by photometrical analysis with orcinol as described by Heller \& Höfer (1975); D-glucose uptake was measured by enzymic analysis of supernatants of reaction suspensions as described by Höfer \& Dahle (1972). The reaction suspension, kept at $30^{\circ} \mathrm{C}$, contained (unless otherwise stated in the legends to Figures or Tables) $5-8 \mathrm{mg}$ dry wt yeast cells $\mathrm{ml}^{-1}$ and $120 \mathrm{~mm}$-potassium phosphate buffer, pH 4.5 (or, in experiments with glucosamine, $120 \mathrm{mM}$-Tris/citric acid buffer, $\mathrm{pH}$ 6.0). Transport was started by addition of the particular sugar at the chosen concentration. $\mathrm{H}^{+}$-cotransport was monitored in unbuffered cell suspensions with a pH electrode connected to a PHM $62 \mathrm{pH}$ meter (both from Radiometer, Copenhagen, Denmark); the $\mathrm{H}^{+} /$sugar stoicheiometry was calculated as described in detail by Höfer \& Misra (1978) and Hauer \& Höfer (1982).

ATP determination. The intracellular ATP content was determined enzymically (test combination, Boehringer) in $\mathrm{HClO}_{4}$-extracts $(0.5 \mathrm{M})$ of yeast cells after neutralization with $1 \mathrm{M}$-triethanolamine/10 $\mathrm{M}-\mathrm{KOH} / 1 \mathrm{M}$-acetic acid $(1.5: 0 \cdot 4: 0 \cdot 1$, by vol.). The increase in absorbance due to NADPH was measured at $366 \mathrm{~nm}$ in an Eppendorf photometer.

Anaerobic transport. Experiments under anaerobic conditions were done in a closed acrylic-glass cuvette with $30 \mathrm{ml}$ reaction suspension $\left(10-15 \mathrm{mg}\right.$ dry wt yeast cells $\left.\mathrm{ml}^{-1}\right) \mathrm{kept}$ at constant temperature $\left(30^{\circ} \mathrm{C}\right)$ under a flow of purified nitrogen $(99.96 \%$ pure; Messer Griesheim, Düsseldorf, FRG) for at least 15 min before addition of transport substrates. All additions were made either as solids or in solutions deaerated with nitrogen. Samples withdrawn for analysis were quickly treated in the same way as samples from aerobic experiments.

Chemicals. All enzymes and coenzymes were from Boehringer; ${ }^{1+} \mathrm{C}$-labelled carbohydrates were purchased from Amersham. [ $\left.{ }^{3} \mathrm{H}\right] 6-D O G$ was kindly supplied by Dr W. Tanner, University of Regensburg, FRG. Oligomycin was from Serva, carbonylcyanide $m$-chlorophenylhydrazone (CCCP) and 2,4-dinitrophenol (DNP) were from Sigma, Dio-9 was from Gist-Brocades (Delft, The Netherlands). All other chemicals were of reagent grade (Merck). Solutions were made up using deionized glass-distilled water.

\section{RESULTS}

\section{Transport under aerobic conditions}

Kinetic characterization of the glucose transport system. The uptake of all sugars tested exhibited saturation kinetics (Table 1). Values of $K_{\mathrm{T}}$ for D-glucose, 2-DOG and glucosamine were considerably lower than those for other sugars. Moreover, only 2-DOG and glucosamine were accumulated intracellularly, reaching maximum intracellular concentrations of 50 and $44 \mathrm{~mm}$ at corresponding external concentrations of 2 and $3 \mathrm{mM}$, respectively. D-Glucose competitively inhibited the uptake of 2-DOG and glucosamine and vice versa. Contrary to this, D-glucose had no significant effect on the transport of the other sugars, which in turn, were without effect on D-glucose uptake. These results demonstrate that in $S$. pombe there is an accumulating transport system for glucose, 2-DOG and glucosamine, and a facilitated-diffusion system of rather low effective affinity for the other monosaccharides. The phenomenon of exchange transport observed when D-glucose was added to cells preloaded with either 2-DOG or glucosamine (Fig. $1 a, b)$ further supports the above conclusion. In addition, only D-glucose and 2-DOG but not 3-OMG nor 6-DOG induced exchange transport in cells preloaded with glucosamine (Fig. $1 \mathrm{~b}$ ). 
Table 1. Accumulation and kinetic parameters of various sugars in S. pombe, and mutual inhibition of sugar uptake by glucose or of glucose uptake by other sugars

All experiments were done under aerobic conditions at $30^{\circ} \mathrm{C}$ in $120 \mathrm{~mm}$-potassium phosphate buffer, $\mathrm{pH} 4.5$ (except for glucosamine: Tris/citric acid buffer, $\mathrm{pH} 6$ ) with a $5 \%$ (fresh wt/vol.) yeast suspension (about $8-10 \mathrm{mg}$ dry $w \mathrm{ml}^{-1}$ ). The cells were de-energized by adding $50 \mu \mathrm{M}$-CCCP or $0.5 \mathrm{~mm}-\mathrm{DNP}$.

\begin{tabular}{|c|c|c|c|c|c|c|}
\hline \multirow[b]{2}{*}{$\begin{array}{l}\text { Transport } \\
\text { substrate }\end{array}$} & \multirow[b]{2}{*}{$\begin{array}{c}K_{\mathrm{T}} \\
(\mathrm{mM})\end{array}$} & \multirow{2}{*}{$\begin{array}{c}V_{\mathrm{T}} \\
{\left[\mathrm{nmol}_{\mathrm{min}^{-1}}\right.} \\
\left.(\mathrm{mgdry} \mathrm{wt})^{-1}\right]\end{array}$} & \multirow[b]{2}{*}{$\begin{array}{l}\text { Intracellular } \\
\text { accumulation }\end{array}$} & \multirow{2}{*}{$\begin{array}{c}\text { Outflow } \\
\text { after } \\
\text { addition of } \\
\text { uncoupler }\end{array}$} & \multicolumn{2}{|c|}{$\begin{array}{c}\text { Inhibition of } \\
\text { uptake }\end{array}$} \\
\hline & & & & & Sugars & Glucose \\
\hline D-Glucose & 3 & 50 & $-*$ & $-*$ & & \\
\hline 2-Deoxy-D-glucose & 2 & 36 & 25 -fold & + & + & + \\
\hline Glucosamine & 17 & 5 & 15-fold & + & + & + \\
\hline 3-O-Methyl-D-glucose & 178 & 135 & - & - & - & - \\
\hline 6-Deoxy-D-glucose & 45 & 29 & - & - & - & - \\
\hline D-Xylose & 206 & 130 & - & - & - & - \\
\hline D-Arabinose & 283 & 167 & - & - & - & - \\
\hline
\end{tabular}

* Since glucose is rapidly catabolized there was virtually no free intracellular glucose detectable. Hence, neither accumulation nor outflow from preloaded cells could be demonstrated.

These results demonstrated that glucose, 2-DOG and glucosamine are translocated by a single common carrier, which was designated as the 'glucose transport system'. To characterize the energetics of the glucose transport system 2-DOG, and occasionally glucosamine, were chosen as the transport substrate. The carrier possessed the highest effective affinity for 2-DOG, which is not metabolized intracellularly (Foury et al., 1977) and only slowly phosphorylated to a very small extent (unpublished results). Glucosamine, on the other hand, was potentially a useful substrate since it bears a net positive charge due to association with $\mathrm{H}^{+}$at the $\mathrm{pH}$ values (between 5.0 and 6.5) used ( $\left.K_{\mathrm{a}}=7.75\right)$. Experiments with $\left[{ }^{14} \mathrm{C}\right]$ glucosamine proved that it also was not catabolized by $S$. pombe cells since no radioactivity was released as $\mathrm{CO}_{2}$ (results not shown), and the radioactivity was completely recovered in cell suspensions when an uncoupler was added to preloaded cells (Fig. 2).

Energetics of the glucose transport system. The time course of 2-DOG accumulation is shown in Fig. 2. Similar results were also obtained for glucosamine (not shown). The accumulation of 2-DOG and glucosamine was prevented by uncouplers, when added before the substrate. Uncouplers induced an outflow of accumulated 2-DOG and glucosamine down to the diffusion equilibrium when added to preloaded cells. Fig. 2 also demonstrates that the accumulation of 2-DOG in control suspensions was reduced after about $15 \mathrm{~min}$ incubation, indicating an inhibition of cell metabolism by accumulated 2-DOG. This was confirmed by measurements of cell respiration which was stimulated up to 8-fold during the first 5 min following 2-DOG addition and then rapidly declined to the level of resting cells after about $30 \mathrm{~min}$ (data not shown). However, in the presence of ethanol (the solvent for the uncouplers) the accumulation of 2-DOG continued, eventually reaching higher values than in control suspensions. Correspondingly, cell respiration was also stimulated by added ethanol (about 12-fold). Hence, ethanol was used as an advantageous energy source in subsequent aerobic experiments in $S$. pombe because it penetrates biological membranes by physical diffusion and does not interfere with any carrier mechanism.

By comparison of the transport kinetics in energized (by ethanol) and de-energized (by uncoupler) cells the effect of energy supply on the carrier mechanism can be assessed. Energy supply did not significantly change the effective affinity of the carrier for substrate (2-DOG in this experiment); however, the maximum influx was enhanced 6-fold [from 5.9 to $35.7 \mathrm{nmol} \mathrm{min}^{-1}$ (mg dry wt) ${ }^{-1}$ (energized compared with de-energized cells)]. Thus, the supply of energy enhanced the turnover rate of the carrier.

Evidence for $\mathrm{H}^{+} /$substrate cotransport. When 2-DOG was added to unbuffered cell suspensions energized by either ethanol (120 mM) or glucose ( $5 \mathrm{mM})$, the onset of 2-DOG uptake 

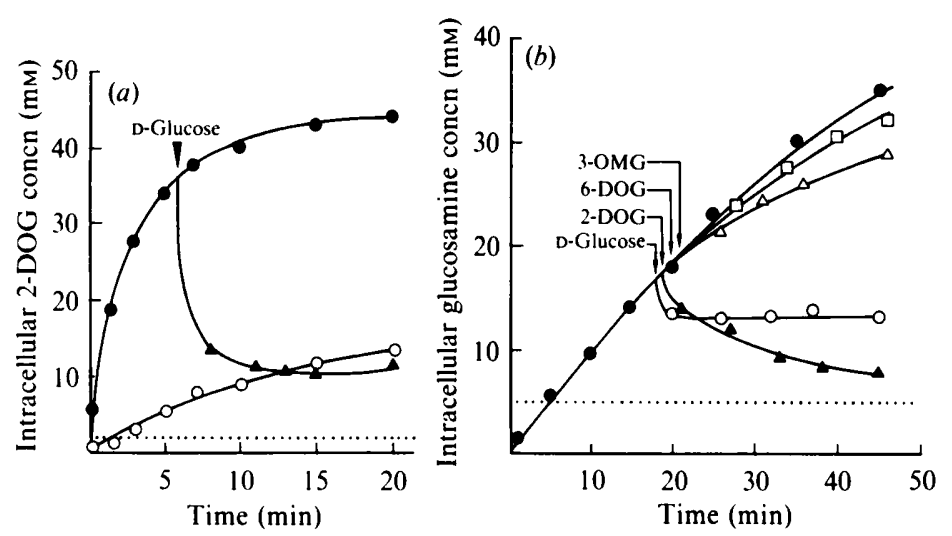

Fig. 1. (a) Inhibition by D-glucose of 2-DOG uptake and the phenomenon of exchange transport. Uptake of 2-DOG (2 mM); O, uptake of 2-DOG in the presence of $50 \mathrm{~mm}$-D-glucose; $\triangle$, outflow of 2-DOG from preloaded cells induced by the addition of $50 \mathrm{~mm}$-D-glucose as indicated by the arrow (exchange transport). (b) Exchange transport of glucosamine $(5 \mathrm{~mm})$ induced by $50 \mathrm{~mm}-2-\mathrm{DOG}(\Delta)$ or $50 \mathrm{mM}-\mathrm{D}-\mathrm{glucose}(\mathrm{O})$ added as indicated; $50 \mathrm{mM}-3-\mathrm{OMG}(\square)$ or $50 \mathrm{mM}-6-\mathrm{DOG}(\triangle)$ failed to induce glucosamine outflow from preloaded cells. The dotted lines correspond to the diffusion equilibria. The curves given are representative of three $(a)$ or four $(b)$ repeated experiments.

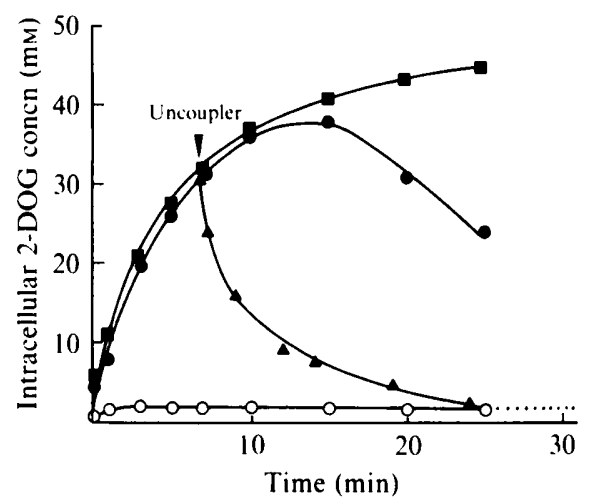

Fig. 2. Effect of uncouplers on 2-DOG accumulation. Uncouplers were dissolved in ethanol; its concentration in cell suspensions was $120 \mathrm{~mm}$. C, Control uptake of 2-DOG ( $2 \mathrm{mM})$ without further additions; $\square$, uptake of 2-DOG in the presence of $120 \mathrm{~mm}$-ethanol; $\Delta$, outflow of 2-DOG from preloaded cells induced by the addition of either $50 \mu \mathrm{M}-\mathrm{CCCP}$ or $0.5 \mathrm{mM}-\mathrm{DNP}$ (arrowed); $0,2-\mathrm{DOG}$ accumulation inhibited by uncoupler added $5 \mathrm{~min}$ before the sugar. Similar results were obtained in cell suspensions incubated with glucosamine instead of 2-DOG. The dotted line corresponds to the diffusion equilibrium. The results given are representative of three repeated experiments.

was accompanied by a distinct alkalinization of the suspensions. This indicated $\mathrm{H}^{+}$-cotransport induced by $2-\mathrm{DOG}$. Fig. 3 shows increasing rates of alkalinization with increasing concentration of added 2-DOG. No $\mathrm{H}^{+}$-cotransport was induced by sugars transported by the facilitated-diffusion system, viz. 3-OMG or D-xylose (see Fig. 8). A double reciprocal plot of $\mathbf{H}^{+}$cotransport rates against 2-DOG concentration measured in $S$. pombe cells energized either with glucose (Fig. 3 inset) or with ethanol (not shown) was linear with a half-saturation constant close to that of 2-DOG uptake. This is indicative of coupled transport of $\mathrm{H}^{+}$and 2-DOG. Comparison of the fluxes of $\mathrm{H}^{+}$and of 2-DOG revealed stoicheiometries of $\mathrm{H}^{+} / 2-\mathrm{DOG}$ cotransport of 0.3 and 0.4 in cells energized by glucose or ethanol, respectively. The stoicheiometry was fairly constant under various physiological conditions, e.g. when the reaction temperature was lowered to $10^{\circ} \mathrm{C}$ or when anaerobic conditions or certain metabolic inhibitors were applied (Table 2). These 


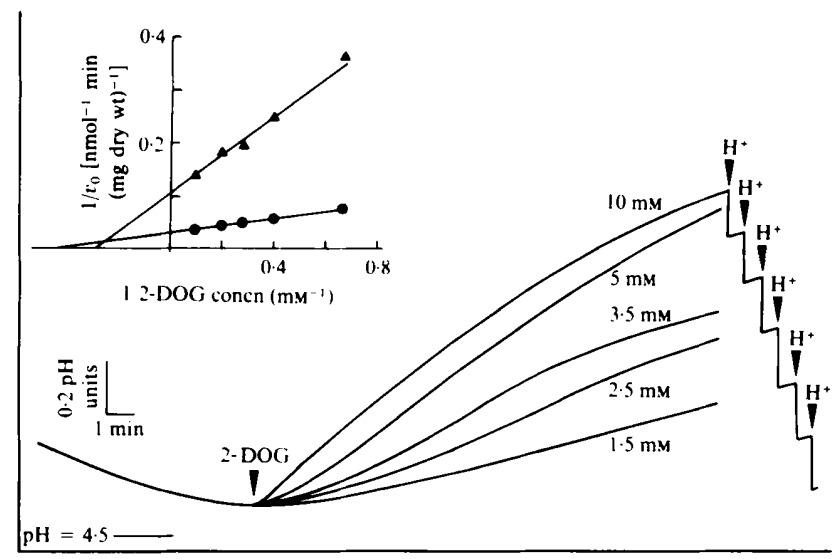

Fig. 3. Continuous recording of the $\mathrm{pH}$ of unbuffered cell suspensions during 2-DOG uptake. Cells were energized with $5 \mathrm{mM}$-D-glucose. Numbers above individual curves give the 2-DOG concentration added at the arrow. The curves are tracings of original recordings shifted to one common origin at the arrow. At the end of each run the $\mathrm{pH}$ recording was calibrated by successive additions of known amount of $\mathrm{H}^{+}(0.5 \mu \mathrm{mol} \mathrm{HCl}$ into $30 \mathrm{ml}$ cell suspension $)$ in order to calculate the initial influx of $\mathbf{H}^{+}$induced by 2-DOG transport. Simultaneously, samples of the cell suspension were withdrawn and analysed for 2DOG influx. The tracings shown are representative of two experiments with cells energized with Dglucose and three additional experiments with cells energized with ethanol. Inset: double reciprocal plot of the kinetics of both the initial $\mathrm{H}^{+}(\Delta)$ and 2-DOG $(0)$ influx. The similarity of the two halfsaturation constants $\left[K_{\mathrm{T}}(2-\mathrm{DOG})=2.1 \mathrm{mM}, K_{\mathrm{T}}\left(\mathrm{H}^{+}\right)=3.7 \mathrm{mM}\right]$ indicates $\mathrm{H}^{+} / 2-\mathrm{DOG}$ cotransport. The ratio of the maximum initial influx of $\mathrm{H}^{+}\left[9.6 \mu \mathrm{mol} \mathrm{min}^{-1}(\mathrm{mg} \text { dry wt })^{-1}\right]$ and of 2-DOG [33.3 $\mu \mathrm{mol}$ $\mathrm{min}^{-1}\left(\mathrm{mg}\right.$ dry $\mathrm{wt}^{-1}$ ] gives an $\mathrm{H}^{+} / 2$-DOG stoicheiometry of $0 \cdot 3$.

\section{Table 2. Stoicheiometry of $\mathrm{H}^{+} / 2-D O G$ symport under different physiological conditions}

Experimental conditions were as in Table 1. The inhibitors $\left(50 \mu \mathrm{g} \mathrm{Dio-9} \mathrm{ml}^{-1}, 10 \mu \mathrm{g}\right.$ oligomycin $\mathrm{ml}^{-1}$, both dissolved in methanol, and $1 \mathrm{~mm}$-DCCD, dissolved in ethanol) were added $45 \mathrm{~min}$ before the sugars. Aerobic cells were energized with $120 \mathrm{~mm}$-ethanol, anaerobic cells with $5 \mathrm{~mm}$-D-glucose. $v_{0}$, Initial influx; $n$, number of experiments.

\begin{tabular}{|c|c|c|c|c|}
\hline \multirow[b]{2}{*}{ Conditions } & \multirow{2}{*}{$\begin{array}{c}\text { Temperature } \\
\left({ }^{\circ} \mathrm{C}\right)\end{array}$} & \multicolumn{2}{|c|}{$v_{0}\left[\mathrm{nmol} \min ^{-1}(\mathrm{mg} \text { dry } w \mathrm{t})^{-1}\right]$} & \multirow{2}{*}{$\begin{array}{l}\text { Stoicheiometry } \\
\mathrm{H}^{+} / 2-\mathrm{DOG}\end{array}$} \\
\hline & & $\mathrm{H}^{+}$uptake & 2-DOG uptake & \\
\hline \multicolumn{5}{|l|}{ robic } \\
\hline $\mathrm{mM}-2-\mathrm{DOG}$ & 30 & 3.9 & $11 \cdot 5$ & $0 \cdot 35$ \\
\hline \multirow[t]{2}{*}{$\mathrm{mM}-2-\mathrm{DOG}$} & 30 & $8 \cdot 3$ & 16.5 & 0.5 \\
\hline & 10 & 2.5 & $6 \cdot 3$ & 0.4 \\
\hline+ Oligomycin & 30 & $2 \cdot 2$ & 7.6 & 0.3 \\
\hline + Dio-9 & 30 & $2 \cdot 3$ & 6.5 & 0.35 \\
\hline$+\mathrm{DCCD}$ & 30 & 0 & 0 & 0 \\
\hline \multirow{2}{*}{$\begin{array}{l}\text { naerobic } \\
m M-2-D O G\end{array}$} & 30 & 6.8 & 14.7 & 0.45 \\
\hline & 10 & $2 \cdot 6$ & $5 \cdot 8$ & 0.45 \\
\hline
\end{tabular}

results suggest that $\Lambda \bar{\mu}_{\mathbf{H}^{+}}$is the driving force for substrate accumulation by the glucose transport system in $S$. pombe.

The electrogenicity of $\mathrm{H}^{+} / 2$-DOG cotransport was tested by applying millimolar concentrations of the lipophilic cation tetraphenylphosphonium (TPP + ) (Liberman \& Topali, 1969). Due to its hydrophobic nature, TPP ${ }^{+}$readily penetrates biological membranes by physical diffusion, whereby its mass flow depolarizes the membranes (Hauer \& Höfer, 1978; Prasad \& Höfer, 1986). In cell suspensions at $\mathrm{pH} 6, \mathrm{TPP}^{+}(10$ or $20 \mathrm{~mm})$ completely prevented 2-DOG 


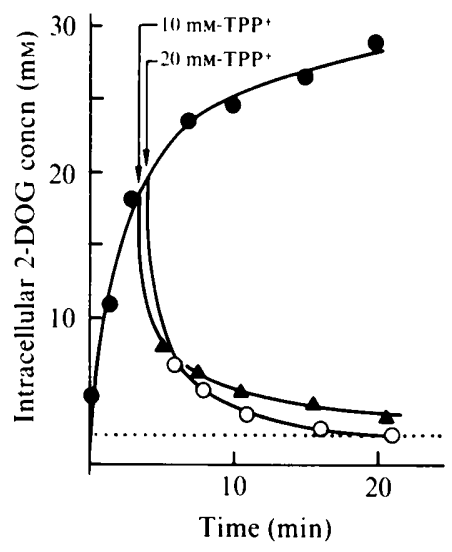

Fig. 4.

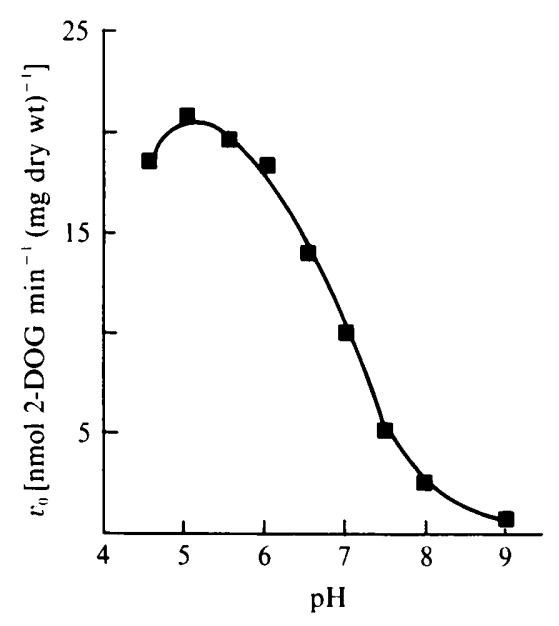

Fig. 5.

Fig. 4. Outflow of 2-DOG (2 mM) from preloaded cells induced by depolarizing concentrations of the lipophilic cation $\mathrm{TPP}^{+}$. $-\mathrm{No} \mathrm{TPP}^{+} ; \boldsymbol{\Lambda}, 10 \mathrm{mM}-\mathrm{TPP}^{+} ; \mathrm{O}, 20 \mathrm{~mm}-\mathrm{TPP}^{+}$. Experimental conditions were as in Fig. 2, $\mathrm{pH}=6.0$. The dotted line corresponds to the diffusion equilibrium. The results given are representative of two repeated experiments.

Fig. 5. Dependence of the initial influx $\left(v_{0}\right)$ of 2-DOG $(2 \mathrm{mM})$ on the $\mathrm{pH}$ of the cell suspension ( $120 \mathrm{~mm}$ potassium phosphate buffer). The data plotted are means from four repeated experiments.

accumulation or, when added to preloaded cells, caused a complete outflow of accumulated sugar (Fig. 4). Virtually the same results were obtained with glucosamine (data not shown). The effect of $\mathrm{TPP}^{+}$on 2-DOG accumulation was considerably less pronounced at $\mathrm{pH} 4.5$ (data not shown), where the proton electrochemical gradient generally consists mainly of a $\Delta \mathrm{pH}$ (Höfer $e t$ al., 1985).

Since the uptake of substrates induced a stoicheiometric cotransport of $\mathrm{H}^{+}$and was dependent on the membrane potential it was concluded that the glucose transport system of $S$. pombe is a $\mathrm{H}^{+}$-symporter. $\mathrm{H}^{+}$-symport mechanisms display a characteristic $\mathrm{pH}$ dependence of transport velocity which slows down as the population of protonated carrier molecules decreases at higher $\mathrm{pH}$ values. The effect of extracellular $\mathrm{pH}$ on $2-\mathrm{DOG}$ influx in energized $S$. pombe cells is shown in Fig. 5. When the initial rates of 2-DOG uptake, at $\mathrm{pH}$-values between 5.5 and 7.5 , were plotted against the $\mathrm{H}^{+}$concentration in a double-reciprocal plot, a straight line was obtained. From its intercept with the abscissa the apparent half-saturation constant of the carrier with $\mathrm{H}^{+}$ was calculated to be $10^{-7} \mathrm{M}\left(\mathrm{p} K_{\mathrm{a}}=7 \cdot 0\right)$. The initial influx of D-glucose exhibited a similar $\mathrm{pH}$ dependence. A distinctly different pattern of $\mathrm{pH}$ dependence was obtained for the initial influx of D-xylose, a substrate of the facilitated-diffusion system. D-Xylose influx decreased steadily from $\mathrm{pH} 4.5$ to 9.5 , where it was still about one-third of that at $\mathrm{pH} 4.5$ (data not shown).

Effect of inhibitors of the plasma membrane ATPase. A $\mathrm{H}^{+} /$substrate symport depends on a functioning plasma membrane ATPase generating the driving force of substrate translocation, $\Delta \bar{\mu}_{\mathrm{H}^{+}}$. Two of the known inhibitors of the plasma membrane ATPase in $S$. pombe, Dio-9 and $N, N^{\prime}$-dicyclohexylcarbodiimide (DCCD) (Delhez et al., 1977; Foury et al., 1977) as well as oligomycin, an inhibitor of the mitochondrial ATPase, were tested for their effect on 2-DOG transport in cells energized by ethanol (Fig. 6). Cells were preincubated with inhibitor for $45 \mathrm{~min}$ before addition of 2-DOG. Both 2-DOG uptake (Fig. $6 a$ ) and $\mathrm{H}^{+}$-cotransport (Fig. $6 b$ ) were measured. After preincubation with inhibitors, three samples were withdrawn for measurement of the intracellular ATP concentration. DCCD was the most powerful inhibitor of 

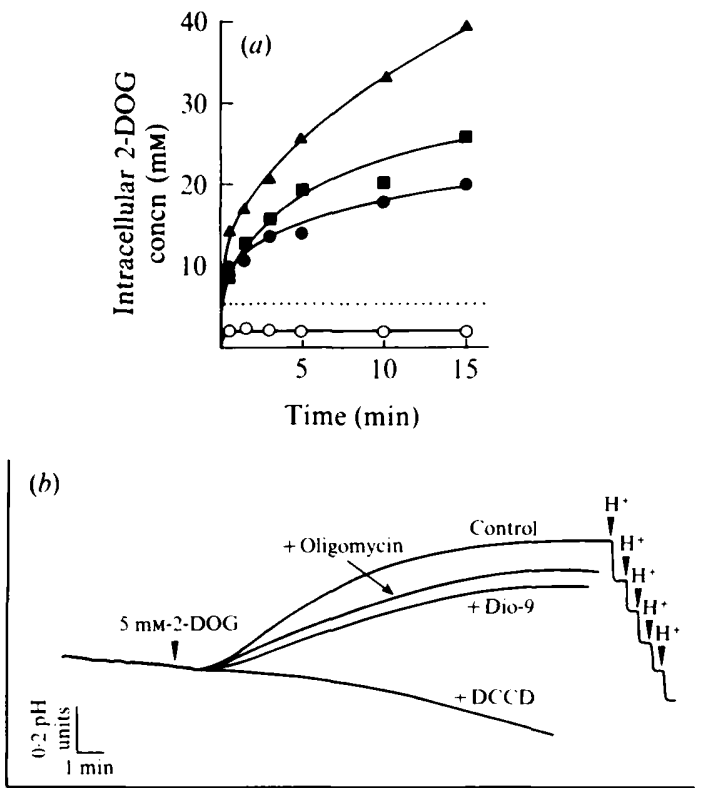

Fig. 6. Effect of inhibitors of the plasma membrane ATPase on $\mathrm{H}^{+} / 2-\mathrm{DOG}$ symport. (a) Uptake of 2DOG $(5 \mathrm{mM})$ in cells energized with $120 \mathrm{~mm}$-ethanol. Dio $9\left(50 \mu \mathrm{g} \mathrm{ml}^{-1}\right)(O)$ or oligomycin $\left(10 \mu \mathrm{g} \mathrm{ml}^{-1}\right)$ $(\square)$, both dissolved in methanol, or $1 \mathrm{~mm} \mathrm{DCCD}(1 \mathrm{~mm})(\mathrm{O})$, dissolved in ethanol, were added $45 \mathrm{~min}$ before the transport substrate: $\boldsymbol{\Delta}$, control without inhibitors. The dotted line corresponds to the diffusion equilibrium. (b) Tracings of the $\mathrm{pH}$ recordings corresponding to the uptake curves in $(a)$. The tracings were shifted to one common origin indicated by the arrow. The $\mathrm{pH}$ values of the particular cell suspensions (unbuffered) at the time of 2-DOG addition were as follows: control, $5 \cdot 5$; oligomycin, $6 \cdot 5$ : Dio-9, 6.5; and DCCD , 6.9. At the end of each run the $\mathrm{H}^{+}$recordings were calibrated by successive additions of $0.5 \mu \mathrm{mol} \mathrm{HCl}$ (suspension volume $30 \mathrm{ml}$ ). The results shown are representative of three repeated experiments (cf. also Table 2).

transport; intracellular ATP concentration was also lowered to $0.3 \mathrm{~mm}$. Dio-9 and oligomycin both inhibited uptake by about $50 \%$. The intracellular ATP concentration was $1.8 \mathrm{mM}$ in the presence of either of these two inhibitors (ATP concentration in energized cells without inhibitor was $9.9 \mathrm{~mm}$ ). Corresponding to the inhibited uptake of 2-DOG, $\mathrm{H}^{+}$-cotransport was also lowered, maintaining the $\mathrm{H}^{+} / 2$-DOG stoicheiometry constant at about $0 \cdot 4$ (Table 2). The fact that the symport stoicheiometry was maintained at different extents of inhibition of 2-DOG uptake further supported the conclusion that the glucose transport system is an $\mathrm{H}^{+}$-symporter.

\section{Transport under anaerobic conditions}

Under anaerobic conditions ethanol cannot serve as a metabolic substrate. $S$. pombe cells without an external energy source were virtually incapable of uptake of both 2-DOG (Fig. 7a) and glucosamine (data not shown). However, anaerobic uptake of D-glucose was reduced by only $30 \%$ and was still inhibited by high 2-DOG concentrations (Fig. $7 b$ ), indicating that the same glucose transport system was operating as under aerobic conditions. When $10 \mathrm{~mm}$-D-glucose was used as anaerobic energy source the accumulating capacity of the $\mathrm{H}^{+}$-symporter was completely restored (Fig. 7a). The occurrence of $\mathrm{H}^{+}$-cotransport induced by the onset of 2-DOG transport (Fig. 8) demonstrated that $\Delta \bar{\mu}_{\mathrm{H}^{+}}$was also the driving force for transport under anaerobic conditions. The anaerobic $\mathrm{H}^{+} / 2$-DOG symport displayed a stoicheiometry of 0.45 which was close to that observed under aerobic conditions (Table 2). 

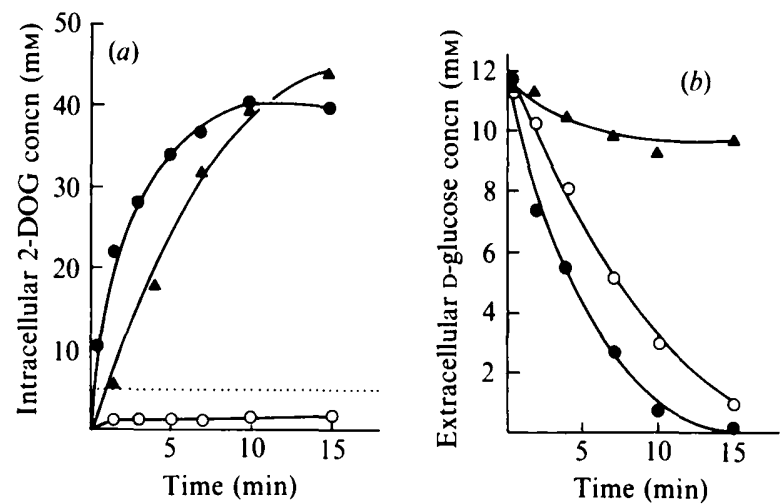

Fig. 7. Anaerobic transport and accumulation of 2-DOG (a) and anaerobic consumption of D-glucose (b). $\mathrm{O}$, Uptake in anaerobic cells without further additions; $\mathbf{O}$, transport in aerobic cells as control; $\mathbf{\Delta}$, uptake in anaerobic cells ( $a$ ) of 2-DOG energized with D-glucose $(5 \mathrm{mM})$, and $(b)$ of D-glucose inhibited by 2 -DOG $(20 \mathrm{mM})$; substrate concentration, $5 \mathrm{mM}$. The dotted line in $(a)$ corresponds to the diffusion equilibrium. Similar results also were obtained with glucosamine instead of 2-DOG. The data given are representative of four $(a)$ or three $(b)$ repeated experiments.

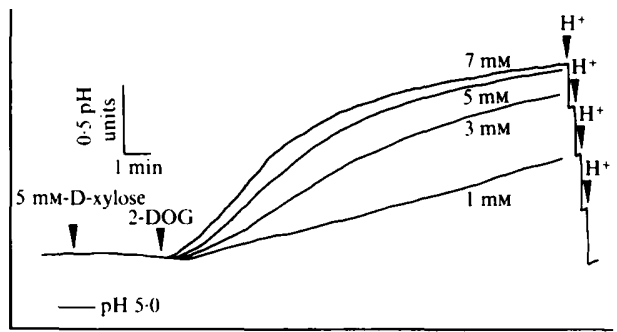

Fig. 8. Continuous recording of the $\mathrm{pH}$ of unbuffered anaerobic cell suspensions during 2-DOG uptake. Conditions were as in Figs 3 and $6(b)$ except that cell suspensions were kept anaerobic throughout the experiment. Note that $5 \mathrm{mM}$-D-xylose, a sugar not translocated by the glucose transport system, failed to trigger $\mathrm{H}^{+}$-cotransport. The curves shown are representative of a total of nine measurements with two different cell batches.

\section{DISCUSSION}

The experimental work presented in this paper provided evidence that D-glucose and its analogues 2-DOG and glucosamine are transported in $S$. pombe by an $\mathrm{H}^{+}$-symporter. 2-DOG and glucosamine are accumulated in energized cells and, unlike the yeast Rhodotorula glutinis (Höfer, 1971), the molecular operation of the symporter is independent of energy supply, catalysing facilitated-diffusion under de-energized conditions. In this respect, it resembles some bacterial transport systems (Winkler \& Wilson, 1966). The D-glucose analogues 6-DOG and 3OMG, as well as the aldopentoses D-xylose and D-arabinose, enter the cells by a facilitateddiffusion system independent of metabolic energy. The apparent half-saturation constant of the $\mathrm{H}^{+}$-symporter with protons $\left(\mathrm{p} K_{\mathrm{a}}=7\right)$ corresponds to those reported for $R$. glutinis $\left(\mathrm{p} K_{\mathrm{a}}=6 \cdot 7\right.$; Höfer \& Misra, 1978) and for the green alga Chlorella vulgaris $\left(\mathrm{p} K_{\mathrm{a}}=6.9 ;\right.$ Komor \& Tanner, 1974).

The $\mathrm{H}^{+} / 2$-DOG stoicheiometry of the $S$. pombe $\mathrm{H}^{+}$-symporter was rather low $(0 \cdot 3-0 \cdot 5$; cf. Table 2). This is doubtless due to recycling of protons by the plasma membrane $\mathrm{H}^{+}$-ATPase. The mass flow of positive charges into the cells by the $\mathrm{H}^{+}$/substrate cotransport must be electrically compensated for during the transport process. Only at the early stage of cotransport can charge compensation be effected, for example by a transient efflux of $\mathrm{K}^{+}$as demonstrated in $R$. glutinis 
$\left(\mathrm{H}^{+}: \mathrm{K}^{+}: \mathrm{D}-\mathrm{xyl}\right.$ lose stoicheiometry was $1: 1: 1$ for the initial $60-90 \mathrm{~s}$; Hauer \& Höfer, 1982). In $S$. pombe no $\mathrm{K}^{+}$efflux was detected following the onset of 2-DOG uptake. Obviously, the electrogenic $\mathrm{H}^{+} / 2-\mathrm{DOG}$ cotransport was electrically compensated for from the beginning mainly by proton recycling, thus reducing the measurable stoicheiometry. The physiological significance of the measured $\mathrm{H}^{+} / 2-\mathrm{DOG}$ stoicheiometry is apparent from the evidence for coupled fluxes of $\mathrm{H}^{+}$and the transported substrate. Our attempts to measure $\Delta \psi$ in $S$. pombe by using micromolar TPP+ concentrations (Hauer \& Höfer, 1978; Boxman et al., 1982; Höfer \& Künemund, 1984; Prasad \& Höfer, 1986) failed. Nevertheless, the results obtained with high $\mathrm{TPP}^{+}$concentrations strongly suggest the participation of $\Delta \psi$ in energizing the uptake and accumulation of both 2-DOG and glucosamine. The effect of inhibitors (DCCD, Dio-9 and oligomycin) of membrane-bound ATPases on 2-DOG and glucosamine accumulation is also consistent with their translocation by an $\mathrm{H}^{+}$-symporter. However, since the inhibitors also lowered the intracellular ATP concentration their impact on transport may be secondary due to a primary effect on mitochondrial ATP production.

The glucose transport system operated under aerobic and anaerobic conditions. However, endogenous anaerobic metabolism could not provide sufficient energy for transport. When energy supply was restored (by adding D-glucose) full transport capacity was regained. In this respect, the anaerobic transport in $S$. pombe closely resembles that in Debaryomyces polymorphus (Schulz \& Höfer, 1986). In this yeast, it is the inability of anaerobic metabolism to energize disaccharide uptake that prevents disaccharide utilization under anaerobic conditions (Kluyver effect; cf. Sims \& Barnett, 1978). Although our work on $S$. pombe did not deal with transport and utilization of disaccharides, it has a bearing on the elucidation of the Kluyver effect, since the results obtained confirmed the strict dependence of anaerobic sugar uptake on a sufficient energy supply, which thus determines the ability to utilize sugars anaerobically.

Anaerobic 2-DOG uptake induced a measurable $\mathrm{H}^{+}$-cotransport in cells energized with D-glucose. Superficially, this observation might be surprising since D-glucose was also taken up in symport with protons. However, any measurable $\mathrm{H}^{+}$-cotransport is always transient as long as the plasma membrane ATPase does not fully compensate for the symported protons. When the steady state between $\mathrm{H}^{+}$-expulsion by the ATPase and $\mathrm{H}^{+}$-uptake by the symporter becomes disturbed by an additional load on the symporter (2-DOG addition) another transient noncompensated $\mathrm{H}^{+}$-cotransport is likely to be observed.

It was the aim of this work to test whether or not sugar uptake in $S$. pombe is mediated by an $\mathrm{H}^{+}$-symporter. The results presented have established the prerequisite for further investigation of the mechanism of energy coupling between the plasma membrane $\mathrm{H}^{+}$-ATPase and the $\mathrm{H}^{+}$symporter by using reconstituted plasma membrane vesicles. Preliminary experiments showed that plasma membrane vesicles reconstituted with pure phospholipids generated a $\Delta \bar{\mu}_{\mathrm{H}^{+}}$(inside acidic and positive) on adding ATP to a vesicle suspension.

F.R.N. was the recipient of a postgraduate fellowship of the Minister of Higher Education of the Arabic Republic of Egypt. The work was supported by a grant to M.H. of the Deutsche Forschungsgemeinschaft (Ho 555).

\section{REFERENCES}

BARnett, J. A. \& Sims, A. P. (1982). The requirement of oxygen for the active transport of sugars into yeasts. Journal of General Microbiology 128, 23032312.

Boxman, A. W., Barts, P. W. J. A. \& Borst-Pauwels, G. W. F. H. (1982). Some characteristics of tetraphenylphosphonium uptake into Saccharomyces cerevisiae. Biochimica et biophysica acta 686, 13-18.

Delhez, J., Dufour, J.-P., Thines, D. \& Goffeau, A. (1977). Comparison of the properties of plasma membrane bound and mitochondria bound ATPase in the yeast Schizosaccharomyces pombe. European Journal of Biochemistry 79, 319-328.
EDDY, A. A. (1982). Mechanisms of solute transport in selected eukaryotic microorganisms. Advances in Microbial Physiology 23, 1-78.

FoURY, F. \& GoFFEAU, A. (1975). Stimulation of active uptake of nucleosides and amino acids by cyclic adenosine 3,5-monophosphate in the yeast Schizosaccharomyces pombe. Journal of Biological Chemistry 250, 2354-2362.

Foury, F., Boutry, M. \& Goffeau, A. (1977). Efflux of potassium induced by Dio-9, a plasma membrane ATPase inhibitor, in the yeast Schizosaccharomyces pombe. Journal of Biological Chemistry 252, $4577-$ 4583 . 
Goffeau, A. \& Boutry, M. (1986). Three protonpumping ATPases in yeast. Microbiological Sciences 3, 164-168.

Goffeau, A. \& Slayman, C. W. (1981). The proton translocating ATPase of the fungal plasma membrane. Biochimica et biophysica acta 639, 197-223.

Goffeau, A., Briquet, M., Colson, A. M., Delhez, J., Foury, F., Labaille, F., Landry, Y., Mohar, O. \& MrENA, E. (1975). Stable pleiotropic respiratorydeficient mutants of a "petite-negative" yeast. In Membrane Biogenesis, pp. 63-97. Edited by A Tzagoloff. New York and London: Plenum Press.

HAUER, R. \& HöFER, M. (1978). Evidence for interactions between the energy-dependent transport for sugars and the membrane potential in the yeast Rhodotorula gracilis (Rhodosporidium toruloides). Journal of Membrane Biology 43, 335-349.

HAUER, R. \& HöFER, M. (1982). Variable $\mathrm{H}^{+}$/substrate stoicheiometries in Rhodotorula gracilis are caused by a $\mathrm{pH}$-dependent protonation of the carrier(s). Biochemical Journal 208, 459-464.

HELlER, K. B. \& HöFER, M. (1975). Temperature dependence of the energy-linked monosaccharide transport across the cell membrane of Rhodotorula gracilis. Journal of Membrane Biology 21, 261-271.

HÖFER, M. (1971). A model of the monosaccharide uphill transporting cell membrane system in yeast. Journal of Theoretical Biology 33, 599-603.

HÖFER, M. \& DAHLE, P. (1972). Glucose repression of inducible enzyme synthesis in the yeast Rhodotorula gracilis: effect of the cell membrane transport. European Journal of Biochemistry 29, 326-332.

HÖFER, M. \& KÜNEMUND, A. (1984). Tetraphenylphosphonium ion is a true indicator of negative plasma membrane potential in the yeast Rhodotorula glutinis. Biochemical Journal 225, 815-819.

HöFER, M. \& MISRA, P. C. (1978). Evidence for a proton/sugar symport in the yeast Rhodotorula gracilis (glutinis). Biochemical Journal 172, 15-22.

Höfer, M., Nicolay, K. \& Robillard, G. (1985). The electrochemical $\mathrm{H}^{+}$-gradient in the yeast Rhodotorula glutinis. Journal of Bioenergetics and Biomembranes 17, 175-182.
KOMOR, E. \& TANNER, W. (1974). The hexose-proton cotransport system of Chlorella. Journal of General Physiology 64, 568-581.

Liberman, E. A. \& Topali, V. P. (1969). Permeability of bimolecular phospholipid membranes for lipidsoluble ions. Biofizika 14, 452-461.

Niemietz, C., Hauer, R. \& HöFer, M. (1981). Active transport of charged substrates by a proton/sugar cotransport system. Biochemical Journal 194, 433441.

PraSAD, R. \& HöFer, M. (1986). Tetraphenylphosphonium is an indicator of negative membrane potential in Candida albicans. Biochimica et biophysica acta 861, 377-380.

SCARboROUGH, G. A. (1976). The Neurospora plasma membrane ATPase is an electrogenic pump. Proceedings of the National Academy of Sciences of the United States of America 73, 1485-1488.

SCHUlz, B. \& HöFER, M. (1986). Utilization of lactose in non-respiring cells of the yeast Debaryomyces polymorphus. Archives of Microbiology 145, 367371.

Sims, A. P. \& BarnetT, J. A. (1978). The requirement of oxygen for the utilization of maltose, cellobiose and D-galactose by certain anaerobically fermenting yeasts (Kluyver effect). Journal of General Microbiology 106, 277-288.

Villalobo, A. (1982). Potassium transport coupled to ATP hydrolysis in reconstituted proteoliposomes of yeast plasma membrane ATPase. Journal of Biological Chemistry 257, 1824-1828.

Villalobo, A., Goffeau, A. \& Boutry, M. (1981). Electrogenic proton translocation coupled to ATP hydrolysis by the plasma membrane $\mathrm{Mg}^{2+}$-dependent ATPase of yeast in reconstituted proteoliposomes. Journal of Biological Chemistry 256, 1208112087.

WINKLER, H. H. \& WILSON, T. H. (1966). The role of energy-coupling in the transport of $\beta$-galactosides by Escherichia coli. Journal of Biological Chemistry 241, 2200-2211. 